\title{
Interest of standardization of feet position during 3-dimensional trunk capture
}

\author{
Gregory Notin*, Sophie Pourret, Cyril Lecante, Julie Deceuninck, Nicolas Fraisse, Jean Claude Bernard \\ From 10th International Conference on Conservative Management of Spinal Deformities - SOSORT 2013 \\ Annual Meeting \\ Chicago, IL, USA. 8-11 May 2013
}

\section{Background}

Follow-up visits with scoliotic patients require too many radiologic exams. The ORTEN optical sensor[1,2] captures the external shape of the trunk in 3-dimensions that can be used for intermediary exams and limit the usage of $\mathrm{x}$-rays.

\section{Purpose}

The objective of this study was to demonstrate the value-added benefit of the standardization of the feet posture during the digitization of the patient's trunk.

\section{Methods}

a. Bare skin acquisition. b. Cutaneous benchmark: the first sacral piece (S1), the anterior superior iliac spine (ASIS). c. First acquisition in standard position, feet spread natural, hands at shoulder height into vertical bars, elbows drooping. d. Second acquisition in the same position but with feet in a board position with heels spaced $19 \mathrm{~cm}$ apart [3]. e. A single operator. f. Measuring the angle S1, ASIS right relative to the horizontal and the angle S1, ASIS left relative to the horizontal on the acquisition software Orten file. An average is taken, the angle (S1, ASIS) relative to the horizontal. g. Comparing 24 samples (20 women and 4 men) with two acquisitions. h. Nine samples (7 women and 2 men) are reacquired three days later.

\section{Results}

a. The angle (S1, EIAS) without platform: from $7.8^{\circ}$ to $30^{\circ}$. Average: $16.2^{\circ}$ deviation: $22.2^{\circ}$. b. The angle (S1, EIAS) with platform: from $5.95^{\circ}$ to $34.7^{\circ}$. Average: $15.9^{\circ}$ deviation: $28.75^{\circ}$. c. Difference of $-13^{\circ}$ to $6.2^{\circ}$. Average: $-0.3^{\circ}$ deviation: $19.2^{\circ}$. Variations were observed in both directions with an overestimated gap when using the platform. d. Without platform: Difference after three days $-9.75^{\circ}$ to $10.7^{\circ}$. Average: $-1.4^{\circ}$ deviation: $20.45^{\circ}$. e. With platform: Difference after three days $-8.6^{\circ}$ to $18.25^{\circ}$. Average: $1.4^{\circ}$ deviation: $26.85^{\circ}$. More variation is observed when the platform is used.

\section{Conclusions and discussion}

The trend would be to choose the natural position of the feet in order to obtain an exam as reproducible as possible.

Published: 18 September 2013

\section{References}

1. Cottalorda J, Kohler R, Garin C, Genevois P, Lecante C, Berge B: Orthoses for mild scoliosis : a prospective study comparing traditional plaster mold manufacturing with fast, noncontact, 3-dimensional acquisition. Spine 2005, 30(4):399-405.

2. Cottalorda J, Kohler R, Garin C, Lecante P: Traitement orthopÃ@dique de la scoliose: nouvelle technique de prise dempreinte par proc optique. Arch Pediatr 1997, 4(5):464-467.

3. Gaux JC, Henrard JC, de Maulmont C, Blery M, Bismuth V: [Measurement of leg length inequality using a simple radiologic method]. Journal de radiologie, d"electrologie, et de medecine nucleaire 1974, 55(8-9):615-6.

doi:10.1186/1748-7161-8-S2-P4

Cite this article as: Notin et al.: Interest of standardization of feet position during 3-dimensional trunk capture. Scoliosis 2013 8(Suppl 2):P4.

\footnotetext{
* Correspondence: gregnotin@gmail.com
} Lecante, Lyon, France

(C) 2013 Notin et al; licensee BioMed Central Ltd. This is an Open Access article distributed under the terms of the Creative Commons 